\title{
Fashioning Piety: Women's Dress, Money, and Faith among Senegalese Muslims in New York City
}

\author{
Beth Buggenhagen \\ Indiana University, Bloomington
}

\begin{abstract}
Many Senegalese women migrate to make a living and build themselves up. The distance enables them to resist daily demands on their income and makes it possible for them to save and to invest in long term projects such as home building, their children's education, and family and religious celebrations. Yet, social criticism often blames women for the problems of marriage: such as the high divorce rate, infidelity, and financial squabbling between spouses. In this paper, I focus on the religio us aspects of women's migration; I argue that Murid women deflect criticism of their wealth earned abroad by investing in the signs and symbols of the this Muslim Sufi congregation. By visiting (ziyara), dressing up (sañse), and donating generously to shaykhs (addiya), Murid women display their wealth, convey the strength of the their social networks, and construct themselves as candidates for salvation. Murid women engage in the global economy and preserve their distinctively Murid vision of the world and their place in it. Is it possible to employ a notion of cosmopolitanism, as a practice and a form of consciousness, which is rooted in history and which is universal? The restructuring of the Senegalese state under neoliberal reform and its aftermath in the 1990s and into 2000 has made Muslim global networks important to livelihoods at home and yet, Muslim networks have come under scrutiny globally as the U.S. led Global War on Terror lingers on.
\end{abstract}

[Gender, Migration and Cosmopolitanism, Islam, Senegal] 


\section{Fashioning Piety: Women's Dress, Money and Faith among Senegalese Muslims in New York City}

\section{Elegance}

Just as I saw the shaykh disappear behind the darkened windows of his SUV and his driver began to pull away from the entrance to the Marriott Marquis Hotel, a young devotee hurled himself onto the hood of the vehicle.

"Laay," shouted one of the young men standing near him as he raised his hand over his mouth, "he really loves his shaykh."

"Ndeysaan," said some of the women as they poured out of the revolving door of the hotel, "the poor boy."

With the weeping young man on the hood and several others still clinging to the side rails and doors, the SUV slowly maneuvered into the dense traffic of Times Square. I noticed that a number of bystanders had stopped to stare at the car. They then turned to the group of women that had ushered the shaykh out of the hotel and asked, "What play was that." I thought that perhaps the bystander's confusion was related to the fact that the Marriott Marquis Hotel was also home to the Broadway Marquis Theatre. ${ }^{1}$

Resplendent against the bitter grey November day in ample layers of iridescent pastel fabrics and gauzy scarves, I realized that the women appeared to be in costume to the bystanders. I noticed how conspicuous they were in midtown Manhattan where suits of dark, somber colors were the norm. They stared at the bystanders blankly and continued to talk amongst themselves about what they had just seen. They described the young man's actions as a display of love for the shaykh (religious leader) — as a performance of crazed (dof) devotion. 
In this paper, I focus on how Senegalese Muslim women who belong to the Murid Sufi way fashioned their piety during the visit of a Murid shaykh, Modou Kara Mbacke Noreyni, in 2005. [FIGURE 1 (Kara 003) A poster announcing the ziyara for Modou Kara Mbacke Noreyni.] Religious visits, or ziyara, commonly take place across New York City and provide disciples opportunities to come together as a Muslim community, to fashion their Muslim identity, to make offerings known as addiya, and to receive guidance in a morally fraught place and time and to remain connected to life at home, in Senegal. The young man who threw himself on the car sought to physically absorb the baraka (religious grace) of his spiritual guide, a quality transmittable through objects, like texts, cloth, prayer beads, or even in this case a car. Religious grace is both spiritual and material; Murids say that it holds the promise of salvation, eternal prosperity, and worldly wealth.

Yet, I was struck more by the women's dress than young man clinging to the car entering midtown traffic. As I watched the car carrying the shaykh disappear into the midday traffic, I thought about the work that the women's religious association, or dahira, had performed for this event. For Murids celebrations in New York-the visit of a shaykh from Senegal, meetings of religious associations, family celebrations, and Muslim holidays-women dressed up, cooked enormous amounts of food, and visited one another. To be able to do this one had to have some money, usually one's own. Yet, having money, and displaying it, often got women into trouble. Their struggling male counterparts complained that women squandered their money on dress saying "gaspillage rekk (only wasting)" of women's expenditures for celebrations. Wives were often asked to contribute to the daily expenses of the household, a practice that was generally thought to be the responsibility of men as boroom diel bi, or those who feed others (see also, Babou 2008; Kane 2011). 
Many Senegalese women migrate to make a living and build themselves up. Muslim women have a long history of traveling outside of Senegal through pilgrimage practices to North Africa and the Middle East (Evers Rosander 2005). The distance enables them to resist daily demands on their income and makes it possible for them to save and to invest in long term projects such as home building, their children's education, and family and religious celebrations. Yet, social criticism often blames women for the problems of marriage: such as the high divorce rate, infidelity, and financial squabbling between spouses.

I focus on women's dress and exchange practices, which are not proscribed by Islam, but are an important means for Murid women to achieve religious merit (tuyaaba) and to benefit from the baraka of the shaykh. Through their dynamic dress and exchange practices, Murid women reference local historical practices, which are often referred to by the Murid clergy and others are coosan or custom, as well as Muslim universalism, specifically the call to all Muslims to be modest in dress, to be generous, and to engage in mutual aid (Buggenhagen 2011).

Modou Kara Mbacke's movement professed a Muslim cosmopolitanism by drawing inspiration from Islamic reformism in the Arab Muslim world to claim membership in global Islam while, at the same time, being grounded in Sufi thought and practice particular to Senegal's history (see also Samson 2009). Kara is renowned for deploying unconventional forms of authority. Rather than relying on Muslim scholarship, which underpins many Sufi leaders' claim to authority, Kara's fame derives from the personalized relationship he creates with his followers. He speaks empathetically of their marginalized position in society as unemployed young men or male and female migrants abroad (ibid). He also promulgates a notion of Muslim cosmopolitanism through admonishing his followers to be jekk, or elegant in their dress and comportment as a way of displaying their righteousness. Kara fashions his elegant dress from 
diverse styles in place and time in and out of Senegal such as a turban, an Eastern European knit cap (the uniform of the Modou Modou, as street traders are often called), and a top hat, often combining incongruous elements such as a grand boubou over a western style button down shirt and tie. Most importantly, he views his Islamist inspired Sufi oriented movement as both a means of transforming the Murid congregation in and out of Senegal and the global Islamic Ummah (ibid 259). He sees his form of Islam as a model for non-Senegalese Muslims (ibid 265). His brand of Muslim cosmopolitanism turns on localized Murid histories as well as Islamist conceptions of Islam thought to transcend place and time. ${ }^{2}$ And like all Murids, he sees his central mission as spreading the word of the founding figure of the Murids, Amadou Bamba.

Although women do not directly submit to Sufi shaykhs, a practice known as njebbel, given gender constructs in Islam, their religious associations donate generously to gain an audience with their religious leaders at home in Senegal. At this event, they used money-they wore expensive dress and they gave generously to the visiting shaykh. In fact, Kara's female devotees shined. It is hard to speak of Kara's devotees as wearing Muslim dress, as the term itself is problematic in that there is such diversity in women's dress styles in any one place as well as globally (Akou 2007; Schulz 2007). Yet one thing that can be said of Kara's devotees is their emphasis on Wolof dress, on the grand boubou, the unstructured ten meter garment common throughout Muslim Africa (Heath 1992). The women at the Kara conference chose glossy fabrics, embroidered with shimmering metallic threads and accented with sparkling chokers, and stacks of bracelets that made the requisite sunglasses sensible in the late fall gloom. Senegalese women often discuss the display of skillful and beautiful dress as sañse (Grabski 2009; Heath 1992; Mustafa 2006; Rabine 2002; Scheld 2003; Scheld 2007). Sañse seems to belie the notion of restraint (kersa) in bodily comportment in Islam. Yet displaying and 
distributing cloth is not directed at demonstrating individual wealth or even personal vanity, but rather making visible the strength of women's social networks (Buggenhagen 2008; Cooper 1997; Schulz 2007). The art of sañse is reserved for joyous occasions, such as a naming ceremony, a marriage or any xew (event/happening) such as a party. Importantly these are also occasions during which women are photographed and videotaped, which itself is also a festive event (Buckley 2006; Fall 1999).

Women dressed up for many occasions - for balls and soirées, for nightclubs and family celebrations, but they did not always wear the boubou that was more common among married, adult women. On religious occasions, the boubou was de rigueur for communicating propriety as well as wealth. In fact, Murid men had fashioned a specifically Murid boubou style called the Baye Lahat after one of their beloved leaders. Oftentimes women chose white or members of religious associations dressed in matching cloth bought wholesale; city life affected their fabric choices only in so far as innovation was praised given the vast number of choices of luxury fabric available in New York City. As a strategy to display wealth, sañse conveyed that the members of the women's religious association were in a position to bestow wealth upon the shaykh, in the form of religious offerings called addiya, through which they would receive the promise of paradise. Thus, dressing well indexed their status as women of means, their desire to honor their spiritual leader, and their moral persona as pious and righteous (Heath 1992). This process of incorporating their wealth into the Murid mission is a unique way of facing the problems of accumulation and the perils of migration for Muslim women far from home.

Recent literature has suggested that through travel to Gulf countries as well as to Europe and North America African Muslims have come in contact with forms of Muslim thought and practice beyond sub-Saharan Africa, which are often characterized by scholars and practioners 
alike as universal and more scripturally based than the forms they have historically practiced in their home countries (Bowen 2004; D'Alisera 2004). As a consequence, some women in these communities have adopted forms of dress from afar signaling their membership in this global community of Muslims, in contrast to localized styles of dress (Bernal 1997; Schulz 2007). Though this has been the case for some women in Senegal, predominantly those belonging to Islamist movements, it has not been the case for Murid women in general (or for Murid men for that matter) (Diouf 2000). Why this has not been the case poses an interesting problem that turns on debates over the use of the term cosmopolitanism in relation to Muslim movements and identities. Is it possible to employ a notion of cosmopolitanism, as a practice and a form of consciousness, which is rooted in history and which, at the same time, is universal? In short, how do we understand the diversity of forms of cosmopolitanism across Muslim worlds and how they are historically constituted?

Murid women seek to recreate their particular form of what Mamadou Diouf (2000) has called, "vernacular cosmopolitanism," or what Pnina Werbner has called in other contexts "a situated cosmopolitanism," (Werbner 2008b) as they travel, accumulate wealth and participate in circuits of global capital. Murid women seek to participate in capitalist modernity, processes of globalization, and a universal Islam while at the same time preserving their distinctively Murid and Sufi vision of the world and their place in it. Here I use the terms, "vernacular cosmopolitanism" and "situated cosmopolitanism" to signal the importance of thinking about how Muslim cosmopolitanisms are historically located (see for example Werbner 2008b).

The Murids emerged at the turn of the twentieth century in the context of the French conquest of present day Senegal. Murid men and women sought to preserve and to create localized visions of their worlds, while at the same time, drawing on the universal concepts of 
Islam to create a space for themselves in the new colonial milieu. Today, Murid women reconcile their activities abroad with their definition of who they are at home, in Senegal, by maintaining the centrality of Tuba, the "spiritual metropolis" (Ross 1995) of the Murid way envisioned by their founding figure Amadou Bamba, as a particular place with a history that guides their actions in the present, even as they migrate afar. To maintain the centrality of Tuba in their vision of what Islam is, Murid women abroad seek to participate in the life of the tariqa by attracting the attention of the shaykhs. Dress is central to their strategy of displaying their wealth as a sign of their success in the global economy and signifying their membership and belonging in a historically rooted Muslim cosmopolitanism by investing in Murid signs and symbols.

Women's wealth in and out of Senegal has been subject to moral scrutiny at a time when men are finding marriages more difficult to enter into and sustain as their financial prospects at home have dwindled with that of the state. The restructuring of the state under neoliberal reform and its aftermath in the 1990s and into the 2000s has made these Muslim global networks important to livelihoods at home and yet at the same time, Muslim networks have come under scrutiny globally as the U.S. led Global War on Terror lingers on. Life in New York City has become difficult for Murids engaged in the unofficial economy as street traders. Before the events of 9/11 many Senegalese worked in restaurants and hotels. Many became unemployed after 9/11 as tourism declined and turned to the unofficial economy. Yet trading in the unofficial economy too suffered as the U.S. sought to stem the trade in counterfeit goods, to track informal banking and hawala transfers, and deny undocumented immigrants access to state services such as education, health care, and driver's licenses (Buggenhagen 2010). Many men and women put away their khaftans, boubous and other Wolof clothing, which they said made their Muslim 
identity more apparent, and donned jeans and t-shirts as they sought to support themselves and their families in volatile times.

\section{Murid Cosmopolitanism and the Global War on Terror}

Murid men and women in New York City saw themselves as cosmopolitans because many had traveled extensively throughout Europe, had relatives who had lived in France for several generations, and had already undertaken the Hajj pilgrimage to Mecca. How odd it was that they now found themselves facing new restrictions on their movement and identities in New York City where the U.S. led global War on Terror had spawned new forms of local policing, including searching vendors of counterfeit goods, surveying mosques, and tracking money transfers (Buggenhagen 2010). Even odder given that this is a religious movement that pushed itself to globalize, to embrace international travel, to locate itself at the interstices of the official and unofficial networks of the global economy, and to profit at a time when the Senegalese nation-state itself was in decline. In this respect, Diouf (2000) has argued that the Murids represent a unique cosmopolitanism and a unique temporal trajectory that are not rooted in a Western modernity or resistance to it, or in global Islam, but in West African history, which has always been part and parcel of the global. Importantly, the Murid congregation, with its global reach and its close ties to the spiritual and commercial center of Tuba, Senegal, did not meet the conventional understanding of cosmopolitan as it has circulated in anthropology as that which is not local (Werbner 2008a).

Although the Murid way emerged as an agricultural movement at the turn of the twentieth century in Senegal, Muslims have long been associated with trade in West Africa (Amselle 1971; Amselle 1977; Cohen 1971; Curtin 1975; Hopkins 1973; Stoller 2002). Given their involvement in regional trade networks, many Muslim communities maintained an outlook 
that transcended their particular locality. For many Muslims trade had 'the stamp of divine authority" (Hunwick 1999). As much as it has been imbued with the language of salvation, the Qur'anic language of salvation is replete with economic metaphors; for example, worship and giving alms are referred to as a "profitable commerce (tijara)" (ibid.). It was not surprising then that by the 1970s Murids had turned to trade in the urban areas to escape rural devastation and mounting debt related to the cultivation of peanuts. At first, Murid agricultural migrants were mere scavengers in the urban areas, recycling cleaned-up bits of string, bottles, and cans for sale in the market at the command (ndiggal) of Seriñ Abdoul Lahat Mbacke. Overtime, Murids transformed the strategy of trading in the dry season to make ends meet in lean agricultural cycles into full-time urban settlement (Cruise O'Brien 1988; Diop 1981; Roberts 1996).

Although it might have seemed that urban disciples were in the process of becoming further entrenched in the world market through their trade, "they made a conscious effort to incorporate their unique temporality and rationality into world time by using their own vocabulary, grammar and worldview to understand the world and operate within it" (Diouf 2000). Despite their outward migration, Murid disciples maintained a close connection to shaykhs in Tuba. When Murid disciples first migrated out of the peanut basin to the urban areas of Senegal they established dahira associations, which offered camaraderie, mutual aid and spiritual kinship in unfamiliar places (Babou 2002). Urban male and female disciples congregated once a week in these religious associations during which they recited litanies, contributed cash offerings to the religious hierarchy, and invested in social projects. The dahira provided refuge as well as practical training in urban ways such as business skills for those lacking a French education. The dahira could be a means of finding a business partner or securing the patronage of an established large trader with access to international markets who 
could advance credit and merchandise and enable one to avoid the financial and transactional costs associated with the formal banking sector (Thioub, et al. 1998).

Being able to rely on the social relations that were forged in religious associations for lodging, food, and protection from police was crucial for traders who often worked outside of the official economy beyond the parameters of state regulation or across state boundaries. The patronage of a senior member of the dahira also enabled Murids to engage in financial transactions within the sphere of that which was morally sanctioned in Islam, thus avoiding riba (interest or increase), associated with formal sector economic transactions, and enabling adherence to Qur'anic injunctions against sacrificing religious practice for commercial gain in trade, gambling and speculation. Finally, such patronage relations enabled Murids to follow recommendations that wealth should be used in the service of God, and that capital obtained through wrongdoing to others is avoided (Hunwick 1999).

Since the 1970s, when Murid traders began arriving in New York (Ebin 1992), they have occupied niches in the unregulated economy of New York City, first as street vendors, eventually coming to dominate sections of Harlem with restaurants, hair salons, stores carrying Muslim paraphernalia, movies and music videos and imported specialty foods and tailor shops. Murid migration to the United States increased during the period of Structural Adjustment Programs and devaluation of the currency in Senegal mandated by the World Bank and the International Monetary Fund that began in 1985 (Coombe and Stoller 1994; Diouf 2000; Diouf 2004; Perry 1997). The numbers of Murids in the United States grew after the passing of the U.S. Immigration Reform and Control Act of 1986 that regularized their status (Babou 2002) and the Immigration Act of 1990, which introduced the Diversity Immigrant Visa program that provided 
permanent resident visas to citizens of countries with low immigration rates to the United States (Beck 2008).

Women began travelling in greater numbers to participate in summer festivals and over time established small businesses (Diouf 2004). Women's financial success often surpassed their male counterparts as professionals, business owners, and hair braiders (Babou 2008). Women's wealth became subject to social commentary, and often the subject of the household division of labor and expenses focused on the practice whereby women kept their own earnings and drew on their spouse's earnings to cover household expenses (Babou 2002; Diouf 2004). Often women invested their wealth in Senegal in real estate in Dakar (Tall 1994), in cloth wealth that they circulated during the celebration of family ceremonies, and in shaykhs in Tuba during the annual pilgrimage called the Mággal.

There are as many as thirty dahira associations in New York City (Babou 2002), which meet in gender-restricted groups. One of the most prominent women's dahira associations in New York City is the Dahira Maam Jaara Boussou, which organizes the annual observation of Cheikh Amadou Bamba Day (Salzbrunn 2004). The dahira association not only assists in financing the event, but also plays an important organizational role, providing copious amounts of cooked food and their presence in large numbers in the mediated public gatherings that show the strength of the Murid presence in New York City to other city dwellers and to their compatriots in Senegal.

Although African Muslims comprise only $7 \%$ of the six million Muslims in the U.S. (Diouf 2004), and the Murid community estimates its numbers at about 1,000 to 2,000 members (Salzbrunn 2004), the Murid community has high visibility in the Harlem neighborhood of New York City. In addition to the many shops and restaurants on $116^{\text {th }}$ street Murids also utilize 
space in the Malcolm Shabazz Mosque, an important architectural landmark on $116^{\text {th }}$ street to hold religious observances. They have recently built an Islamic center consisting of a mosque and school at $137^{\text {th }}$ Street and Edgecombe Avenue in 2001 to receive members of the clergy. The Murid Islamic Center becomes the center of activity annually during the commemoration of their founding figure Shaykh Amadou Bamba in New York City through a parade and interfaith dialogue at the United Nations Building.

\section{The Ziyara of Modou Kara Mbacke: Defining Elegance (Jekk)}

The high points of Modou Kara Mbacke's visit to New York City in November 2005 included the conference at the Marriott Marquis Hotel, his arrival at JFK International Airport, which appears on Googlevideo.com and myspace.com, ${ }^{3}$ and his reception of disciples in his room across the street at the Sheraton Hotel. Men and women came from all over the U.S. to seek guidance in their financial and personal affairs as well as counsel for living an upright life in a non-Muslim land. For shaykhs like Kara, the visit offered an opportunity to practice qualities of generosity and munificence that would underpin his claim to an exalted status.

Although Kara was widely known as the "Marabout of the Youth" (Bjarnesen 2007), in his audience in New York, there were as many middle-aged men and women as there were young men. Kara challenged the Murid spiritual hierarchy with the figure of the Khalifa-General at its center as both the political and the spiritual leader. Spiritual authority is most often derived from configuring descent from Amadou Bamba, scholarly learning, the provenance of the wird, (the specific recitation for membership in the Murid way), the silsila (the chain of transmission), performance of miraculous episodes (karamat), and spiritual retreat (khalwa). Although Kara is the grandson of Bamba's youngest brother (Bjarnesen 2007), he does not emphasize the chain of spiritual transmission or initiation based on his genealogical ties. Rather, Kara fashions his 
authority from his claim to be the General of Amadou Bamba, a point driven home by the popular portrait of Kara in military fatigues.

He also challenged the secular nature of the state itself with his positioning as a "morally superior political leader" (Bjarnesen 2007). In 2004, he founded the political party Parti de la Vérité pour le Développement (PVD) and garnered wide support among young men as well as members of the Baye Fall sect of the Murid way. Kara's claims to political power could be seen as based in part on the position of his wife Sokhna Dieng Mbacké, a senator appointed by current President Abdoulaye Wade (Mbow 2008), who had also at one point in time been the head of Radiodiffusion Television Senegalese (RTS), the national television network.

Kara was not only a shaykh on the rise who had engaged in some unusual publicity stunts, such as occupying a downtown Dakar hotel claiming he had been commanded to do so in a vision, he was also a shrewd entrepreneur and aspiring political figure. Kara's disciples established Kara International Exchange to facilitate financial transfers between New York and Dakar in the late 1990s (Gueye 2003; Tall 1994).

In his speech about elegance at the New York conference, the very quality of his voice embodied the idea of what an elegant speaker should be. [FIGURE 2 (Kara 035) Kara at the podium.] Kara was expressive, warm, and he spoke for himself audibly, persuasively, and authoritatively at a podium through several microphones (to facilitate the recording of the event), without the mediation of a griot, though he did have the requisite entourage one would expect with most exalted figures. This was striking as religious specialists often have their speech mediated by a griot to emphasize the shaykh's asceticism and other worldly concerns. Consonant with a Wolof language ideology associating low-ranking persons such as griots with gifted, persuasive and often loud speech and rapid movement and high-ranking persons with 
quiet speech and a reserved comportment, who command other's labor to speak for them, Murid religious leaders did not themselves often speak publicly and when they did their griots amplified their words (Irvine 1989). Kara's media savvy—employing visual and aural media including videos and cassettes, the web and social networking sites, the radio, and the print media — to spread his message was facilitated by his willingness to speak. Yet, this medium is not neutral, his use of media shapes his messages and the audience's reception in large part I would argue because he is such an engaging speaker (Schulz 2003). The medium of videocassettes as a particularly visual form of media enabled Kara to rely less on verbal reasoning and more on visual persuasion and the aesthetics of the image (Schulz 2006). Thus, Kara exemplified his notion of elegance through his sartorial acumen. Although his look often varied, including portraits of him in pin striped suits with knee length jackets and turbans, grand boubous, bow ties, and even black tie and tails, at the New York conference he wore a simple white jellaba and the knit hat that the modou modou street traders favored.

In his widely circulated portraits, Kara was often featured with his hands, gesturing elegantly, which is quite common in West African portraiture. Long slender hands have long been associated with high status and a sign of beauty, not unlinked here to his platform of elegance, in dress, bodily comportment, speech, public personae and moral virtue. His portraits circulated widely in the news media, on television, and cassettes and CDs were even for sale in the market. Moreover as Murid disciples say that they commonly like to carry a portrait of their shaykh with them to aid them in their devotional practices, photos of Kara could be purchased in the market as well (Gueye 2003).

Clearly, as a controversial figure within the Murid way, Kara is worthy of a study in its own right. Yet my focus here is less on his personality and trajectory and more concerned with 
the actions of his female followers in New York City, a subject to which I now turn. Kara's devotees sought to embody the idea of jekk (elegance) promulgated in Kara's sermon that day. As each woman arrived at the event she was greeted with comments such as "yangi sañse" or "danga jekk" meaning that she had mastered the art of dressing well. Elegance has been associated with conveying the dignity of one's lineage (Mustafa 2006), yet in the context in which Kara used it during the conference, elegance had taken on additional meanings such as piety, purity and upright behavior.

Women seated themselves on the left side of the aisle with their bags and video cameras in tow, opposite of the men on the right side, saving chairs for women who arrived late. As they waited some two hours for the shaykh to appear they busied themselves with discussing each other's sartorial acumen, including feeling the quality of each other's cloth, establishing its provenance, the name of the tailor, innovations in cosmetics and hairstyles and their objects of adornment. They took photographs of each other, made videos and discussed dahira affairs. When Kara arrived an elaborate security team shielded him from his more passionate disciples and a media entourage accompanied him as he made his way to the front of the room. [FIGURE 3 (Kara 010) Kara's arrival with security entourage and videographers. One camera of focused on Kara and the second on the audience.] He was seated at the center of a long table in the front of the meeting room behind a collection of microphones. Prior to his taking the podium, he was preceded by several religious scholars who gave talks on righteous living. Kara finally took the podium and delivered a rather short sermon about elegance.

It was on that point that the leader of the women's dahira approached him from the audience. With her sunglasses shielding her eyes she waved the sheer white scarf that covered her head in the air and danced in his direction. She reached under her white eyelet boubou 
embroidered with pink trim and then lifted several bills from her wrapper and placed them in his hands. Her actions caused frenzy among the women. She shouted to them, "Kaay lenn, come all," and motioned towards the podium. The women rose up and placed money in front of Kara one by one. They swayed back and forth with their arms waving, snapped their fingers in the air, and sang his praises. The leader of the women's group continued to call the members of the dahira to contribute twice or even three times as the collective energy of the congregation rose.

\section{Fashioning Piety}

The Murid women's association said that they desired to receive baraka from Kara, to whom like other shaykhs they had limited access (Coulon 1988; Creevey 1996). ${ }^{4}$ They also said that they sought religious merit directly from God known as tuyaaba (for comparison see Buitelaar 1993; Rosander 1998; 2004) through good acts. ${ }^{5}$ Members of the women's associations described acts worthy of merit to include any practice that is good or wholesome such as giving alms, providing hospitality, undertaking ziyara to honor living Sufi figures and to the tombs of those who have deceased, and embarking on the Hajj. Importantly, these acts do not rely on the mediation of a shaykh. Where mediation of a shaykh is sought, women turn to another set of strategies, including donning proper and expensive dress, extending hospitality to the shaykh and his or her entourage, and making offerings directly to shaykhs through dahira associations to draw them into relations of reciprocity with them, which they claim to do altruistically and with great humility.

Religious conferences, such as that organized for Kara, offer opportunities to perform good acts through which women construct their Muslim personhood, to receive guidance on a morally correct life in non-Muslim lands, and to persuade shaykhs to enter into relations of reciprocity with them as members of a religious association. Religious figures are potent persons 
to whom disciples turn to in times of need for matters such as infertility, marital tensions, legal troubles, and success in business. Through ziyara women draw on the cultural and spiritual capital of Islam to bolster their reputation, which is central to their success in trade and ownership of small businesses such as hair braiding, groceries, tailor shops and restaurants, and they avoid moral disapproval for their practices abroad.

Through the display and bestowal of wealth at Muslim conferences, women sought to extend their selves in space and time. Practices of supplication constructed a spatial and temporal domain apart from the mundane. Through dress, the bestowal of cooked food, and addiya offerings women were "initiating a spatiotemporally extending process" (Munn 1992) or a "mode of self expansion" (Weiner 1980). They constructed their individual and collective honor in this life, an "extrabodily component of the self" (Munn 1992), and sought to secure their salvation in the next life. Thus through proper dress, the provision of food, and cash offerings women were seeking to alter others' views of themselves and thus were extending their control beyond themselves; they were crafting reputations (Munn 1992).

\section{Welcoming (Teral) Kara}

Behind the scenes and out of view of the video camera the women's dahira produced an abundance of special dishes and homemade drinks to teral (welcome and honor) Modou Kara Mbacke. As women do not have direct relations with shaykhs as individuals and their opportunities for receiving baraka are more limited, women grilled lamb and cooked fish and garlic scented rice with hot peppers to attract Kara's attention. Commensality is often central to Murid celebrations involving the donation of gifts to religious leaders and their redistribution by them. Women thus not only received religious merit by bringing these special dishes to Kara, they also enabled Kara to demonstrate his largess by inviting others to share in the meals. In 
setting out to teral Kara, women were inviting him to enter into future exchange relations with them.

The exchange of food at the Kara conference reminded me of my field research in Senegal in the spring of 2000 when I had asked women about their relations with shaykhs and their search for baraka. I sought to understand how Islam was central to their lives despite a vast literature focused on the Sufi congregations that argued otherwise. Yet when I asked a members of an mbotaye association (women's neighborhood ritual association) if their preparation of roasted meat and millet couscous to celebrate one's return from the Hajj garnered them baraka they said wagging their fingers, "deedet du baraka, tuyaabale, no, it is not baraka, it is tuyaaba." Convinced that Islam was central to women's lives I continued to press on suggesting that on other occasions during which women provided hospitality such as Ramadan, family celebrations, Muslim feast days, or on ziyara, they must be seeking baraka in return for their efforts. I asked them repeatedly why they were not interested in receiving baraka. Each of the women took turns trying to explain the concept of tuyaaba to me. The women emphasized that religious merit was received directly from God and would secure their place in heaven. ${ }^{6}$ The women's association explained, "tuyaaba comes from doing things that create njariñ (value) including providing hospitality, giving alms, and treats for children." Tuyaaba was also used to describe things that are good and wholesome, such as food, the eating of which is likely to bring merit. And they often turned to stories of the life of the Prophet Muhammad to demonstrate their point.

\section{Practicing Sañse for Kara}

Although dress is central to Muslim ideas about piety, as Muslim men and women in Senegal are known for their elegant dress on Fridays when they don what they call Wolof 
clothing for the day of communal prayer in the mosque, elegance had become particularly important to the Kara movement. Elegance had become the slogan of Kara's religious and political movement in and out of Senegal. Kara's speech often turned on the concept of elegance to mark notions of tahara (purity) central to his claim of moral authority and political leadership in a fraught political terrain in Senegal.

Kara's followers practiced sañse to construct themselves as persons of honor and thus as worthy exchange partners; they made themselves known through the responses they elicited from others (Foster 1995). Dressing well is one of many strategies of display tied to women's stores of cloth wealth and the desire to bestow this wealth on others (Buggenhagen 2008; Heath 1992). Sañse involves accessorizing and properly decorating the body to convey wealth, social rank, and honor. Beauty is not located in the nude body (as in the West) but rather in the body which is accessorized and properly decorated (Biaya 2000). A well-dressed woman conveys the qualities of alal (wealth), which is rooted in the notion of rafet judo (high rank, or a beautiful birth), jom (honor) and kersa (self restraint). The demonstration of these qualities is essential to women's attempts to accumulate wealth and to attract dependents (Irvine 1974).

During Muslim conferences, women reminded me that though they sought to dress elegantly, they did so with restraint and modesty (kersa) appropriate to their attempts to construct their Muslim personhood. Personhood in this context was always discussed as historically constituted, with reference to the Muslim Wolof past, rather than universal (see for comparison, Comaroff and Comaroff 2001). Young women left their bethio (known as the small pagne of seduction) at home and older women tended towards white grand boubous, though certainly one could see many different colors were also appropriate, as long as they reached the floor and covered the length of their arms. Women described proper Muslim dress as consisting 
of wearing long loose gowns that hid their feminine shape and amplified their girth and covering their heads and arms with large loosely wrapped headscarves draped over their head wrappers. Murid men and women both commented on the importance of distinctively Wolof clothing rather than styles imported from Gulf and Arab countries. Murid men and women also focused on other modes of bodily comportment such as ways of sitting, eating and walking that they described as indicative of the importance of their Wolof origins.

Debates over proper Muslim dress can be found elsewhere in the Muslim postcolony (Bastian 1996; LeBlanc 2000; Schulz 2007). In Senegal, over the decades the necklines of women's boubous had become larger, gradually revealing more of women's shoulders and bra straps. Today, many young women go for sleeveless gowns altogether. Further criticism was directed towards younger, unmarried women called disquettes who often wore short skirts and tight blouses to emphasize the curves of the feminine body, fashions which were thought to tempt men to abandon the straight path (Biaya 2000; Nyamnjoh 2005). Yet, for the most part, social criticism surrounding women's dress was primarily about financial discretion rather than admonishing women to cover up so as not to tempt men (Buggenhagen 2008; Heath 1992; Mustafa 1998). To rein in expenses and at the same time demonstrate their financial power women's dahira associations often bought first quality cloth collectively at wholesale prices. In doing so they demonstrated their solidarity on religious occasions.

Murid dress had also become a topic of political debate as young university educated Murid men began to adopt the Baye Lahatte style after the Khalifa General, Abdou Lahatte Mbacke. This style consisted of a floor length three-piece boubou commonly worn by senior men. In time, some young women began to adopt this predominantly male style based, though this was by no means widespread. Other distinctively Murid styles of dress were also subject to 
social commentary such as the njaxas patchwork cloth of the Baye Fall sect, which could be understood as an expression of anti-fashion, produced from a tailor's remnants (Heath 1992; McLaughlin 1997). This form of dress was popular among unemployed youth and those of low social rank.

Yet, even when donning proper dress, women's sartorial displays as forms of communication could also be dangerous (Irvine 1989). Women needed to negotiate their desire to transcend the local and particular to succeed but at the same time they needed to demonstrate their ties to Tuba to avoid moral reprobation. Though women's ostentatious displays enabled men to behave with the restraint characteristic of an austere Muslim masculinity (Heath 1992), such displays of beauty had to be carefully balanced in Muslim Senegal as in Niger where "daraja (Arabic: respectability) is associated with a certain distancing from vulgar (or rather visible) public display" (Cooper 1999). These displays of beauty were also dangerous because they were expensive and could reveal the fragility of a family's budget. In a time characterized by fiscal austerity women employed inventive means of shining from borrowing to buying on credit to create an appearance of affluence without being charged with posing, or puukare, of extending oneself beyond one's means. The danger in displaying and exchanging valued objects, especially money, is that these material goods are not only subject to loss and decay, but to misreading (Keane 2001). Therefore, a discursive frame often accompanies dress and exchange practices to fix their meaning. For this reason women comment on their practice of dressing well by saying, "yangi sañse" or "danga jekk."

\section{Addiya Offerings}

Providing hospitality, dressing well, and making offerings were ways of honoring Modou Kara Mbacke. They were also the ways in which the women constructed themselves as 
candidates for salvation. Offerings were important to men and women because they brought baraka: they were given to the shaykh in return for the promise of paradise and worldly success. [FIGURE 5 (Kara 043) Members of the women's dahira making addiya offerings to Kara.] For men, addiya were often initially made at the time of initiation (njebbel) and thereafter given on a rather regular and somewhat obligatory basis (Cruise O'Brien 1971) during regular visits to one's shaykh. For women, as I mentioned, addiya were collected and donated through dahira associations.

Through their devotional practices women achieved assurance of salvation-of ultimately being in God's presence - in an uncertain moral terrain. Through their participation in the dahira they were plugged into the Murid congregation and their collective offerings presented the possibility of an audience with important religious figures. Through talk about different registers of value and modes of transactions in meetings of religious associations, at conferences and pilgrimages, Murid women framed their exchanges through the language of salvation setting offerings aside from the mundane world of work (Werbner 2003). When cash was given to a shaykh through the language of addiya offerings it was no longer an alienable commodity, a standard of value, or a symbol of the state. Cash signified submission in this world and the next to the path of divine union and recognition of the shaykh as a worthy guide.

\section{Conclusion}

Many Senegalese women migrate to make a living and build themselves up. The distance enables them to resist daily demands on their income and makes it possible for them to save and to invest in long term projects such as home building, real estate speculation, their children's education, and family and religious celebrations. Yet, social criticism often blames women for the problems of marriage: such as the high divorce rate, infidelity, and financial 
squabbling between spouses. In Senegal, with women's increasing financial potential, related in part to their overseas migration, has come a good deal of debate. Social criticism in Senegal has come to rest on women's sartorial success.

At the same time, well-dressed Murid women at home and abroad have caught the eye of the Murid clergy seeking to expand its moral and material might in global Senegal. Women's sartorial and exchange practices during the ziyara of Modou Kara Mbacke in November 2005 were central to the construction of their Muslim personhood and to their identity as Muslim cosmopolitans in an uncertain land and a fiscally troublesome time. Women's dress and exchange practices are an important means for achieving religious merit for benefiting from the baraka of the shaykh. Through their dynamic dress and exchange practices, Murid women reference local historical practices, which are often referred to by the Murid clergy and others are coosan or custom, as well as Muslim universalism, specifically the call to all Muslims to be generous and to engage in mutual aid.

In this paper, I focused on the religious aspects of women's moral persona to argue that Murid women deflect criticism of their wealth earned abroad by investing in the signs and symbols of the this Muslim Sufi congregation. By visiting (ziyara), dressing up (sañse), welcoming (teral), and donating generously to shaykhs (addiya), Murid women display their wealth, convey the strength of the their social networks, and construct themselves as candidates for salvation.

The restructuring of the Senegalese state under neoliberal reform and its aftermath in the 1990s and into 2000 has made Muslim global networks all the more important to livelihoods at home and yet at the same time, Muslim networks have come under increasing scrutiny globally as the U.S. led Global War on Terror lingers on. Hard times wrought by neoliberal economic 
policies and the U.S. led global War on Terror have led critics to focus on women's dress as a sign of women's productive and reproductive potential gone awry. Murid women engage in the global economy and global Islam while at the same time preserving their distinctively Murid vision of the world and their place in it. I have argued that Murid women employ a notion of cosmopolitanism, as a practice and a form of consciousness, rooted in history and which, at the same time, is universal. These debates over Islam and women's dress in and out of Senegal signify important shifts in gender relations, often at the conjuncture of political change, economic liberalization, and calls for moral austerity in tough financial times that transcend the boundaries of the Senegalese nation-state. 


\section{References Cited}

Akou, Heather Marie

2007 Building a New "World Fashion": Islamic Dress in the Twenty-first Century. Fashion Theory 11(4):403-422.

Amselle, J. L.

1971 Parenté et commerce chez les Kookoro. In Development of Indigenous Trade and Markets in West Africa. C. Meillassoux, ed. Pp. 253-266. London: Oxford University Press.

1977 Les négociants de la savane, histoire et organisation sociale des Kooroko (Mali). Paris: Editions Anthropos.

Babou, Cheikh Anta 2002 Brotherhood Solidarity, Education and Migration: The Role of the Dahiras Among the Murid Muslim Community of New York. African Affairs 101:151-70.

2008 Migration and Cultural Change: Money, Caste, Gender and Social Status among Senegalese Female Hair Braiders in the United States. Africa Today 55(2):3-22.

Bastian, Misty

1996 Female 'Alhajis' and Entrepreneurial Fashions: Flexible Identities in Southeastern Nigerian Clothing Practice. In Clothing and Difference: Embodied Identities in Colonial and Post-Colonial Africa. H. Hendrickson, ed. Durham, NC: Duke University Press.

Beck, Linda 
2008 Brokering Democracy in Africa: The Rise of a Clientelist Democracy in Senegal. New York: Palgrave.

Bernal, Victoria

1997 Islam, Transnational Culture, and Modernity in Rural Sudan. In Gendered Encounters: Challenging Cultural Boundaries and Social Hierarchies in Africa. M. GroszNgate and O.H. Kokole, eds. Pp. 131-52. New York: Routledge.

Biaya, T.K.

2000 'Crushing the Pistachio': Eroticism in Senegal and the Art of Ousmane Ndiaye Dago. Public Culture 12(3):707-719.

Bjarnesen, J.

2007 The Baye Fall of Gueule Tapee. A New Religious Path toward Adulthood? Paper presented at the AEGIS Conference.

Bowen, John R.

2004 Does French Islam Have Borders? Dilemmas of Domestication in a Global Religious Field. American Anthropologist 106(1):43-55.

Buckley, Liam

2006 Studio Photography and the Aesthetics of Citizenship in the Gambia, West Africa. In Sensible Objects: Colonialism, Museums and Material Culture. E. Edwards, C. Gosden, and R.B. Phillips, eds. Pp. 61-86. Oxford and New York: Berg.

Buggenhagen, Beth 2008 Beyond Brotherhood: Gender, Religious Authority and the Global Circuits of Senegalese Muridiyya. In New Perspectives on Islam in Senegal: Conversion, Migration, 
Wealth, Power and Femininity. M. Diouf and M.A. Leichtman, eds. Pp. 189-210. New York: Palgrave PRess.

2010 Killer Bargain: The Global Networks of Senegalese Muslims and Policing Unofficial Economies in the War on Terror In Hard Work, Hard Times: Global Volatilities and African Subjectivities. A.-M. Makhulu, B. Buggenhagen, and S. Jackson, eds. Pp. 130-149. Berkeley: University of California.

2011 Are Births Just "Women's Business"? Gift exchange, Value, and Global Volatility in Muslim Senegal. American Ethnologist 38(4):714-732.

Buitelaar, Marjo

1993 Fasting and Feasting in Morocco: Women's Participation in Ramadan. Oxford: Berg.

Cohen, Abner

1971 Cultural Strategies in the Organization of Trading Diasporas. In The Development of Indigenous Trade and Markets in West Africa. C. Meillassoux, ed. Pp. 266-278. London: Oxford University Press for the International Africa Institute.

Comaroff, John L., and Jean Comaroff 2001 On Personhood: An Anthropological Perspective from Africa. Social Identities 7(2):267-283.

Coombe, R., and Paul Stoller 1994 X Marks the Spot: The Ambiguities of African Trading in the Commerce of the Black Public Sphere. Public Culture 7. 
Cooper, Barbara

1997 Marriage in Maradi: Gender and Culture in Hausa Society in Niger, 1900-1989. London: James Currey Ltd.

1999 The Strength in the Song: Muslim Personhood, Audible Capital, and Hausa Women's Performance of the Hajj. Social Text 17(3):87-109.

Coulon, Christian

1988 Women, Islam and Baraka. In Charisma and Brotherhood in African Islam. C. Coulon and D.B. Cruise O'Brien, eds. Pp. 113-134. Oxford: Clarendon Press.

Creevey, Lucy

1996 Islam, Women and the Role of the State in Senegal. Journal of Religion in Africa 26(3):268-307.

Cruise O'Brien, Donal B.

1971 The Mourides of Senegal: The Political and Economic Organization of an Islamic Brotherhood. Oxford: Clarendon Press.

1988 Charisma Comes to Town. Mouride Urbanization, 1945-86. In Charisma and Brotherhood in African Islam. C. Coulon and D.B. Cruise O'Brien, eds. Pp. 135-56. Oxford: Clarendon Press.

Curtin, Philip D.

1975 Economic Change in Precolonial Africa; Senegambia in the Era of the Slave Trade. Madison: University of Wisconsin Press.

D'Alisera, Joan 
2004 An Imagined Geography: Sierra Leonean Muslims in America. Philadelphia:

University of Pennsylvania Pess.

Diop, Momar Couba

1981 Fonctions et activités des dahira Mourides urbains (Sénégal). Cahiers d'études africains $\mathrm{XX}(1-3): 79-91$.

Diouf, Mamadou

2000 The Senegalese Murid Trade Diaspora and the Making of a Vernacular Cosmopolitanism. Public Culture 12(3):679-702.

Diouf, Sylviane

2004 The West African Paradox. In Muslims' Place in the American Public Square. Z.

Bukhari, S. Nyang, M. Ahmad, and J. Esposito, eds. Pp. 268-298: AltaMira Press.

Ebin, Victoria

1992 A la recherche de nouveaux poissons: Stratégies commerciales mourides en temps de crise. Politique Africaine 45:86-99.

Evers Rosander, Eva

2005 Cosmopolites et locales: Femmes senegalaises en voyage. Afrique et histoire 4:103-122.

Fall, Aminata Sow

1999 Vague Memory of a Confiscated Photo. Paris: Revue Noire.

Foster, Robert

1995 Social Reproduction and History in Melanesia: Mortuary Ritual, Gift Exchange, and Custom in the Tanga Islands. . Cambridge: Cambridge University Press.

Grabski, J. 
2009 Making Fashion in the City: A Case of Tailors and Designers in Dakar, Senegal. Fashion Theory 13(2):215-242.

Gueye, Cheikh

2003 New Information and Communications Technology Use by Muslim Mourides in Senegal. Review of African Political Economy 98:609-625.

Heath, Deborah

1992 Fashion, Anti-Fashion and Heteroglossia in Urban Senegal. American Ethnologist 19(1):19-33.

Hopkins, A. G.

1973 An Economic History of West Africa. New York: Columbia University Press.

Hunwick, J.O.

1999 Islamic Financial Institutions: Theoretical Structures and Aspects of their Application in Sub-Saharan Africa. In Credit, Currencies and Culture. African Financial Institutions in Historical Perspective. E. Stiansen and J.I. Guyer, eds. Pp. 72-96. Stockholm: Nordiska Afrikainstitutet.

Irvine, Judith T.

1974 Caste and Communication in a Wolof Village Ph. D. Thesis, Anthropology, University of Pennsylvania.

1989 When Talk Isn't Cheap: Language and Political Economy. American Ethnologist 16:248-267.

Kane, Ousmane 
2011 The Homeland is the Arena: Religion, Transnationalism, and the Integration of Senegalese Immigrants in America. Oxford: Oxford.

Keane, Webb

2001 Money is No Object: Materiality, Desire and Modernity in an Indonesian Society. In The Empire of Things: Regimes of Value and Material Culture. F.R. Meyers, ed. Pp. 65-90. Santa Fe: School of American Research Press.

LeBlanc, $\mathrm{N}$.

2000 Versioning Womanhood and Muslimhood: "Fashion" and the Life Course in Contemporary Bouake, Cote d'Ivoire. Africa 70(3):442-81.

Mbow, Penda

2008 Senegal: The Return of Personalism. Journal of Democracy 19(1):156-69.

McLaughlin, Fiona

1997 Islam and Popular Music in Senegal: The Emergence of a "New Tradition". Africa 67(4):560-581.

Munn, Nancy D.

1992 The Fame of Gawa: A Symbolic Study of Value Transformation in a Massim (Papua New Guinea) Society. Durham: Duke University Press.

Mustafa, Huda Nura

1998 Practicing Beauty: Crisis, Value and the Challenge of Self-Mastery in Dakar 1970-1994, Harvard University. 
2006 La Mode Dakaroise. Elegance, Transnationalism and an African Fashion Capital. In Fashion's World Cities. C. Breward and D. Gilbert, eds. Pp. 177-200. Oxford and New York: Berg.

Nyamnjoh, Francis

2005 Fishing in Troubled Waters: Disquettes and Thiofs in Dakar. Africa 75(3):295324.

Perry, Donna

1997 Rural Ideologies and Urban Imaginings: Wolof Immigrants in New York City. Africa Today 44(2):229-60.

Rabine, Leslie

2002 The Global Circulation of African Fashion. New York and London: Berg. Roberts, Allen F.

1996 The Ironies of System D. In Recycled, Re-seen: Folk Art from the Global Scrap Heap. C. Cerny and S. Seriff, eds. Pp. 82-101. New York: Harry Abrams for the Museum of International Folk Art Santa Fe.

Rosander, Eva Evers

1998 Women and Mouridism in Senegal: The Case of the Mam Diarra Bousso Daira in Mbacke. In Women and Islamization: Contemporary Dimensions of Discourse on Gender Relations. K. Ask and M. Tjomsland, eds. New York: Berg.

2004 Going and Not Going to Porokhane: Mouride Women and Pilgrimage in Senegal and Spain. In Reframing Pilgrimage: Cultures in Motion. S. Coleman and J. Eade, eds. Pp. 69-90. London: Routledge. 
Ross, Eric

1995 Tuba: A Spiritual Metropolis in the Modern World. Canadian Journal of African Studies 29(2):222-259.

Salzbrunn, Monika

2004 The Occupation of Public Space through Religious and Political Events: How Senegalese Migrants Became a Part of Harlem, New York. Journal of Religion in Africa 34(4):468-92.

Samson, Fabienne

2009 Islam, Protest, and Citizen Mobilization: New Sufi Movements. In New Perspectives on Islam in Senegal. M. Diouf and M.A. Leichtman, eds. Pp. 257-272. New York: Palgrave.

Scheld, Suzanne

2003 The City in a Shoe: Redefining Urban Arrica through Sebago Footwear Consumption. City and Society 15(1):109-30.

2007 Youth Cosmopolitanism: Clothing, the City and Globalization in Dakar, Senegal. City and Society 19(2):232-253.

Schulz, Dorothea E.

2003 Political Factions, Ideological Fictions: The Controversy Over Family Law Reform in Democratic Mali. Islamic Law and Society 10(1):132-64. 
2006 Morality, Community, Publicness: Shifting Terms of Public Debate in Mali. In Religion, Media and the Public Sphere. B. Meyer and A. Moors, eds. Pp. 132-151. Bloomington: Indiana University Press.

2007 Competing Sartorial Assertions of Femininity and Muslim Identity in Mali. Fashion Theory 11(2/3):253-280.

Stoller, Paul 2002 Money Has No Smell: the Africanization of New York City. Chicago: University of Chicago Press.

Tall, Serigne Mansour 1994 Les investissements immobiliers d'émigrants sénégalais à Dakar. Revue Européen des Migrations Internationales 10(3):137-51.

Thioub, Ibrahima, Momar Coumba Diop, and Catherine Boone 1998 Economic Liberalization in Senegal: Shifting Politics of Indigenous Business Interests. African Studies Review 41(2):63-89.

Weiner, Annette B.

1980 Reproduction: A Replacement for Reciprocity. American Ethnologist 7(1):71-85. Werbner, Pnina 2003 Pilgrims of Love: The Anthropology of a Global Sufi Cult. Bloomington: Indiana University Press. 
2008a The Cosmopolitan Encounter: Social Anthropology and the Kindness of Strangers. In Anthropology and the New Cosmopolitanism. P. Werbner, ed. Pp. 47-68. Oxford: Berg.

2008b Introduction: Towards a New Cosmopolitan Anthropology. In Anthropology and the New Cosmopolitanism. P. Werbner, ed. Pp. 1-32. Oxford: Berg. 


\section{Endnotes}

${ }^{1}$ The ziyara of Modou Kara Mbacke took place on 20 November 2005.

${ }^{2}$ Many Senegalese Murids disagree with Kara's reformist tendency and would argue that Murid thought and practice is both historical and part and parcel of Islam as s singular, universal faith. ${ }^{3}$ Googlevideo.com, myspace.com (accessed on 6/23/2008).

${ }^{4}$ Coulon further points out "even if women are excluded from public places of worship, nothing prevents them from having baraka, worshipping saints, or becoming agents of a particular marabout." "Women, Islam and Baraka," p. 116. See also, Creevey, "Islam, Women and the Role of the State in Senegal," p. 291.

${ }^{5}$ Evers Rosander noted that her female interlocutors emphasized the importance of their quest for "tiyaba," "Women and Muridism in Senegal: The case of the Mam Diarra Bousso Daira in Mbacke," in Women and Islamization: Contemporary Dimensions of Discourse on Gender Relations, ed. K. Ask, and Marit Tjomsland (Oxford and New York: Berg, 1998). I use "tuyaaba" based on the Dictionnaire wolof-français et français-wolof by Jean-Léopold Diouf, which defines the word as, "Grâce divine à la suite d'une bonne action." Though I suspect it may be related to the Arabic tayyib meaning all that is good and wholesome such as things, deeds, beliefs, persons, or foods.

${ }^{6}$ Both men and women seek religious merit and the cumulative acts are tallied on the Day of Judgment and will ensure their entry into paradise (Buitelaar 1993:121). 